\title{
EFFECT OF FERMENTATION MIXTURE AND PARTICLE SIZE ON BIOGAS PRODUCTION FROM ORGANIC AND AGRICULTURAL WASTES
}

\author{
A. Awny ${ }^{1}$ and Reham S. A. Faid Allah ${ }^{1}$
}

\begin{abstract}
Six digesters made from transparent plastic with a capacity of $10 l$ (digestion volume of 7.5 l) were used for producing biogas. Four different organic wastes were used (fresh cattle dung, cotton stalks, water hyacinth and sugar beet). The digesters were experimented under six different fermentation mixtures ( $A, B, C, D, E$ and $F$ ) and three different particle sizes (5, 10 and $15 \mathrm{~mm}$ ).Digesters performance was evaluated through measuring daily gas production, cumulative biogas production, methane production and chemical analysis for biogas slurry such as nitrogen percentage and $\mathrm{pH}$ value. The experimental results revealed that the maximum daily biogas production and cumulative biogas values were $8.03 \mathrm{l}$ and $108.3 \mathrm{l}$ respectively and also the maximum methane production value was $6.16 \mathrm{l}$ for mixture $D$ and particle size of $5 \mathrm{~mm}$. as the highest nitrogen percentage and $\mathrm{pH}$ values were $4.3 \%$ and 6.83 for the mixture $C$ and $B$ respectively and particle size of $5 \mathrm{~mm}$.
\end{abstract}

Keywords: Digester; Methane; Cotton stalks; Size reduction

\section{INTRODUCTION}

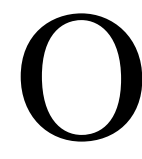
ne of the most important problems that facing the world today is the shortage in fossil fuel such as coal, electricity, crude oil, natural gas, etc. where, energy supplied (received) from the fossil fuel is not easily recycled (reprocessed) and take a long time to form, hence is exhaustible and not renewable. So, the only solution was to move to new and renewable sources of energy such as Biomass, geothermal, ocean waves, hydro, wind and solar energy. On the other hand, in Egypt crop residues and the animal wastes was assessed 40 million mega gram annually (Agricultural Economics Bulletin, 2016). Biomass energy was the perfect solution to get out of the previous two problems by eliminating accumulated wastes and providing a renewable energy source.

Lecturer; Agric. Eng. Dept.; Fac. of Agric.; Zagazig Univ.; Egypt. 
Biogas production considered one of the biomass energy applications where, the biomass wastes are held in a digester and the gas is produced from a four steps process namely, hydrolysis, acidogenesis, acetogenesis, and methanogenesis. Biogas is composed of (50-70) \% Methane, (30-40) $\%$ carbon dioxide, (1-10) \% Hydrogen, (1-3)\% Nitrogen and trace amount such Oxygen, Carbon monoxide and Hydrogen sulphide. Biogas has an ignition temperature ranged from $650{ }^{\circ} \mathrm{C}$ to $750{ }^{\circ} \mathrm{C}$ and is considered lighter than air with a percentage of $20 \%$. The calorific value of biogas is $25 \mathrm{Mj} / \mathrm{m}^{3}$ and the burning efficiency in conventional stoves at (60-70) \% $\mathrm{CH}_{4}$ is $60 \%$ (Ukpai and Nnabuchi, 2012). Therefore, it can be used for heating, cooking and lightning as well using in internal combustion engines to drive machines, to operate water pumps and to generate electricity because of its high content of octane. In addition to, the digester slurry is considered a good fertilizer. Many researches were carried out to enhance the quality and quantity of biogas from different fermentation mixtures. The effect of mixture type on biogas generation was studied where, potato waste, sugar beet waste, water hyacinth, baggas and cattle dung were used as follow: 1- (Potato waste+ sugar beet levels) 2- (Cattle dung) 3- (Water hyacinth + cattle dung). 4-(baggas + cattle dung).The maximum values of $\mathrm{CH}_{4}$ were $75,69.7 \%$ and $68.6 \%$ for mixture of 1, 3, 4 respectively and the percentage of $\mathrm{CO}_{2}$ ranged from 31.65 to $37.46 \%$ while the average of $\mathrm{H}_{2} \mathrm{~S}$ contents ranged from 2017.6 to 2622 ppm (ELTawil and Belal, 2009). (Raheman and Mondal, 2012) investigated the effect of mixing cow dung with Jatropha seed cake (JSC) on biogas generation. The highest value of produced Biogas was found $0.17 \mathrm{~m}^{3}$ at JSC in comparison to $0.166 \mathrm{~m}^{3}$ in case of cow dung slurry alone. Further gas production from $\mathrm{kg}$ of the mixture of Jatropha seed cake and cow dung was greater than that produced from Jatropha seed cake and cow dung slurry alone and was higher when Jatropha seed cake percentage in the mixture was within $25 \%$. The content of Nitrogen in the bio digested Jatropha seed cake slurry was increased by $5.9 \%$ as compared to Jatropha seed cake alone and using it as a fertilizer produced better growth of tomato and maize crops. Also, Several searches revealed that biogas potential increased from organic particulate matter throughout mechanical size reduction (Palmowski and Muller, 2000) and 
(Hartmann et al. 2000) where the physical and chemical construction of lignocellulose cause difficulty and slow in microbial hydrolysis of lignocellulose .microbial hydrolysis of lignocellulose is a difficult and slow process, due to the physical and chemical structure of lignocellulose. The lignin is strongly connected with hemicellulose, which covers the cellulose and therefore a physical barrier is created for the hydrolytic enzymes. Moreover, the cellulose organizes itself in crystalline structures, which are also hard to degrade. Finally, a small surface area of large particles leads to that the microorganisms are able to attack the fibres and collapse their structures Angelidaki and Ahring, 2000). To enhance the biodegradability of lignocellulosic materials, many methods have been studied, having the main goal of increasing the connection of lignin with the degradable part of biofibres, and thereby increasing the surface area and accessibility to microbial attack. The influence of mechanical pretreatment of sisal fiber to decrease the particle size on biogas production was evaluated. The results revealed that methane production was inversely proportional to particle size. The value of methane yield was raised by $23 \%$ when the fibres were cut to $2 \mathrm{~mm}$ size and was $0.18 \mathrm{~m}^{3} \mathrm{CH}^{4} / \mathrm{kg}$ volatile solids for untreated fibres while, was $0.22 \mathrm{~m}^{3} \mathrm{CH}_{4} / \mathrm{kg}$ volatile solids (Mshandete et al. 2006).

So, the aim of the present study is to investigate the effect of particle size reduction as a pre-treatment method and fermentation mixture of cotton stalks, water hyacinth and sugar beet wastes with fresh cattle dung on the biogas production.

\section{MATERIALS AND METHODS}

This study was carried out between April and May 2017 at Faculty of Agriculture, Zagazig University, Egypt in order to study The effect of mixture type and particle size on biogas yield from organic and agricultural wastes

\section{Materials}

\subsection{Organic and agricultural wastes}

Fresh cattle dung (CD), cotton stalks (CS), water hyacinth (WH) and sugar beet wastes (SBW) were used under all treatments of this study with different ratios. These mentioned wastes were collected from private farms in Diarb negm, Sharkia Governorate. All of wastes were reduced in 
the range of $5,10,15 \mathrm{~mm}$ particle sizes by grinding using a stationary shredder with an adaptable sieves (model sh300,power 50kW, speed 1450 rpm and number of cutters 72). All wastes used for the study were not dried before use and no chemical treatment was carried out on the wastes before use. Plastic containers were used in order to store all particle sizes at $4{ }^{0} \mathrm{C}$ to be experimented. The grinding wastes were mixed with different fixed ratios (A,B,C,D,E and F) and analyzed for chemical characteristics as shown in table (1). Then a formed mixture of organic wastes was mixed with water to arrive at a total solid content and all digesters were filled at the beginning with starter

Table (1): Chemical analysis of different mixtures.

\begin{tabular}{|c|c|c|c|c|c|c|c|c|}
\hline Components & RH, \% & $\begin{array}{c}\text { Total } \\
\text { solides, } \\
\%\end{array}$ & $\begin{array}{c}\text { Volatie } \\
\text { solides, } \\
\%\end{array}$ & PH & $\begin{array}{c}\text { Carbon } \\
\text { Nitrogen } \\
\text { ratio }\end{array}$ & $\begin{array}{c}\text { Total } \\
\text { nitrogen } \\
, \%\end{array}$ & $\begin{array}{c}\text { Organic } \\
\text { Carbon, } \\
\%\end{array}$ & Ash, \% \\
\hline Cattle dunge & 88.6 & 11.4 & 86.4 & 6.93 & 28 & 2.3 & 12.6 & 13.6 \\
\hline Cotton stalks & 48 & 52 & 92 & 6.9 & 56 & 1.24 & 10.6 & 8 \\
\hline Sugar beet wastes & 91.2 & 8.8 & 76.6 & 6.7 & 19 & 1.4 & 9.5 & 23.4 \\
\hline Water hyacinth & 92.7 & 7.3 & 79.4 & 7.2 & 17.5 & 1.3 & 11.3 & 20.6 \\
\hline Mixture (A) & 80.5 & 19.5 & 82.6 & 6.95 & 30.25 & 1.6 & 10.5 & 17.4 \\
\hline Mixture (B) & 75.87 & 24.13 & 83.5 & 6.9 & 32.4 & 1.32 & 8.25 & 16.5 \\
\hline Mixture (C) & 78.25 & 21.75 & 82.28 & 6.9 & 30 & 1.2 & 7.9 & 17.72 \\
\hline Mixture (D) & 77.35 & 22.65 & 85.62 & 6.92 & 30.4 & 1.7 & 10.71 & 14.38 \\
\hline Mixture (E) & 82.75 & 17.25 & 82.65 & 6.97 & 30.75 & 1.3 & 8.13 & 17.35 \\
\hline Mixture (F) & 84.7 & 15.3 & 85.3 & 6.9 & 30.2 & 1.6 & 9.9 & 14.7 \\
\hline
\end{tabular}

\subsection{The anaerobic digester}

Six transparent plastic containers of capacity 101 with a digestion volume of 7.51 were used as digesters. They were painted in black to keep out light because of the sensitive of bacteria. Each digester was connected to a plastic cylinder which received the produced gas through delivery tube has a valve to regulate gas flow. Also, the plastic cylinder was attached to a scale to be used as a gas measuring device as shown in Fig. (1). No heat was applied to the setup. But temperature was read daily. 


\section{Methods}

\subsection{Experimental conditions}

All experiments were carried out under the following parameters:-

- Six different fermentation mixture feed concentrations

A $(25 \%$ of cattle dung $+25 \%$ of cotton stalks $+25 \%$ of sugar beet wastes $+25 \%$ of water hyacinth)

B $(50 \%$ of cotton stalks $+25 \%$ of sugar beet wastes $+25 \%$ of water hyacinth)

C $(25 \%$ of cotton stalks $+25 \%$ of sugar beet wastes+ $50 \%$ of water hyacinth)

D ( $50 \%$ of cattle dung $+25 \%$ of cotton stalks $+25 \%$ of water hyacinth)

E $(25 \%$ of cotton stalks $+50 \%$ of sugar beet wastes $+25 \%$ of water hyacinth)

F $(50 \%$ of cattle dung $+25 \%$ of sugar beet wastes $+25 \%$ of water hyacinth)

- Three different particle sizes of $(5,10$ and $15 \mathrm{~mm})$

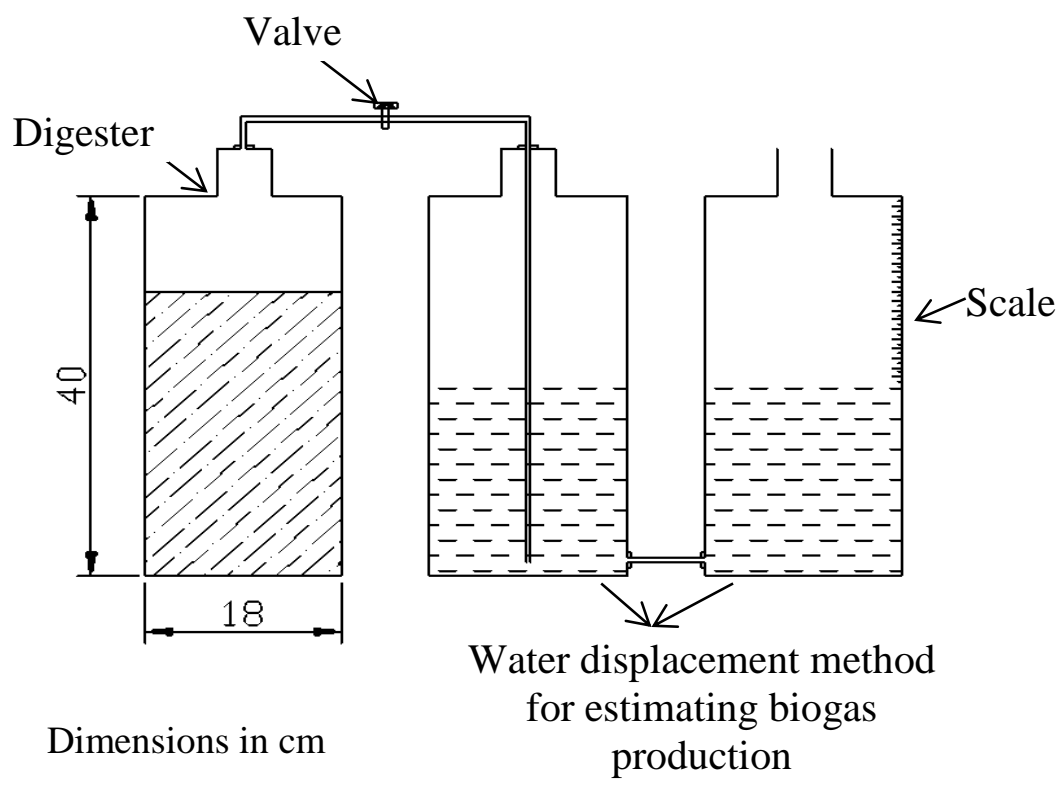

Fig. (1): The external view of the manufactured digester.

\subsection{Measurements}

All treatments were evaluated taking into consideration the following indicators: 


\subsubsection{PH}

A digital $\mathrm{PH}$ meter was used to monitor the $\mathrm{PH}$ value of material to determine the action of methanogens, which use the carbon dioxide, acids and hydrogen generated by non-methane producing bacterial

\subsubsection{Daily biogas production}

The volume of produced biogas was measured by a wetted displacement method by means of a transparent 101 calibrated plastic cylinder as used by Gosch et al (1983) using the following equation:

$$
\begin{aligned}
& V=\frac{V_{m} \cdot \mathrm{P}_{\mathrm{m}} \cdot \mathrm{T}}{P \cdot \mathrm{T}_{\mathrm{m}}} \\
& V=\frac{V_{m} \cdot \mathrm{T}}{\mathrm{T}_{\mathrm{m}}}
\end{aligned}
$$

\section{Where:}

$\mathrm{V}$ : biogas volume at STP, $\mathrm{ml}$.

$\mathrm{V}_{\mathrm{m}}$ : biogas volume at room temperature, $\mathrm{ml}$.

T: standard temperature, $0{ }^{0} \mathrm{C}\left(273{ }^{\circ} \mathrm{K}\right)$

$\mathrm{T}_{\mathrm{m}}$ : room temperature in ${ }^{0} \mathrm{~K}$

\subsubsection{Methane and carbon dioxide content}

The volumes of $\mathrm{CH}_{4}$ and $\mathrm{CO}_{2}$ in biogas were estimated by the concentrated alkaline absorption method using the potassium hydroxide $(\mathrm{KOH})(40 \%)$. The $\mathrm{KOH}$ device consists of glass U-tube shape with 12 $\mathrm{mm}$ internal diameter filled with $\mathrm{KOH}$ (Ezekoye and Okek, 2006). The U-tube attached with tap in order to adjust the solution level with atmospheric pressure after $\mathrm{CO}_{2}$ removal. The tube was installed with samples injection as a biogas inlet and with gas outlet to release gases after $\mathrm{CO}_{2}$ removal as shown in Fig. 2

The percentage of $\mathrm{CO}_{2}$ in biogas was calculated as follows:

Percentage of $\mathrm{CO}_{2}=\left[\left(\mathrm{V}_{1}-\mathrm{V}_{2}\right) / \mathrm{V}_{1}\right] \times 100$

Where

$\mathrm{V} 1$ : biogas volume before removal of $\mathrm{CO}_{2}, \mathrm{ml}$

V2: $\mathrm{CH}_{4}$ volume and the other gases after removal of $\mathrm{CO}_{2}, \mathrm{ml}$

Percentage of $\mathrm{CH}_{4}=100 \%-\left[\mathrm{CO}_{2} \%+3 \%\left(\mathrm{H}_{2} \mathrm{~S}\right.\right.$ and other gases $\left.)\right]$

Vol., \% (Abdel-Hadi and abd El-Azeem 2008)

Where, 
$3 \%$ is the average content of $\mathrm{H}_{2} \mathrm{~S}$ and other gases in biogas corresponding to $(\mathbf{G T Z}, \mathbf{1 9 9 9 )}$

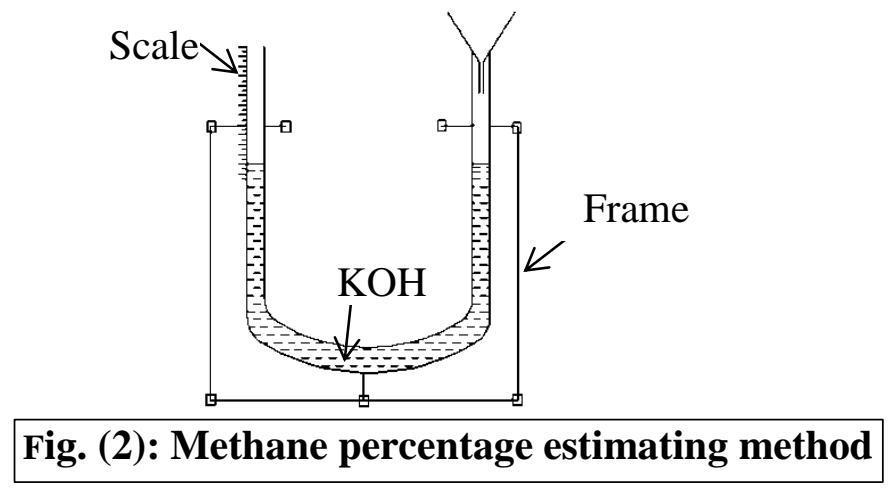

\subsubsection{Total solids (Ts)}

After the end of fermentation different samples were taken from the slurry and dried in the oven at $105{ }^{\circ} \mathrm{C}$ for 24 hours and weighed to determine total solids according to the next equation:

Total solids (TS) $\%=\left[M_{d} / M_{w}\right] \times 100$

Where,

$\mathrm{M}_{\mathrm{w}}$ : the mass of wet sample

$\mathrm{M}_{\mathrm{d}}$ : the mass of dry sample

\subsubsection{Total volatile solids}

Different samples of slurry and raw wastes were dried in a muffle furnace at $550{ }^{\circ} \mathrm{C}$ for 2 hours and the percentage of total volatile solids attained from the following equation (Faure and Dschamps, 1990):

Total volatile solids $(\mathrm{TVS}) \%=\left[\left(\mathbf{M}_{d}-\mathbf{M}_{\text {ash }}\right) / M_{d}\right] \times 100$

Where:

$\mathrm{M}_{\text {ash }}$ : the mass of ash

\subsubsection{Organic matter and organic carbon:}

After estimating ash percentage organic matter and organic carbon were calculated as a percentage using the following equations:

Organic matter $(\mathrm{OM}) \%=100 \%-\operatorname{ash}(\%)$

Organic carbon $(\mathrm{OC}) \%=$ TVS $(\%) / 1.724$

\subsubsection{Total nitrogen}

Kjeldahl method was used to determine the organic nitrogen in the slurry and the raw wastes by digesting $5 \mathrm{gm}$. solid samples or $5 \mathrm{ml}$ liquid samples as a first step using $10 \mathrm{ml}$ of concentrated sulfuric acid with 0.1 
copper and then $50 \mathrm{ml}$ of sodium hydroxide (40\%). The resulting volume was adjusted by diluted water to $100 \mathrm{ml}$. Kjeldahl unit was used for distillation as a second step where, $5 \mathrm{ml}$ saturated boric acid solution received the released ammonia. In the last step ammonia was estimating by titration.

\section{RESULTS AND DISCUSSION}

\section{Effect of fermentation mixtures and particle sizes on daily and cumulative biogas production}

Daily biogas production at different particle sizes for different fermentation mixtures is shown in Fig.3. The results showed that the biogas production rate was low through the first ten days for all treatments, this is due to decomposition process needs to some times to convert complexes components to either materials that responsible of biogas production and then increase to be the maximum rate at the 14 days. It can be noticed that the biogas production rate increased by decreasing particle size. This is due to a larger surface area makes a higher degree contact between the microorganism and substrate so that the biogas production increased. The results indicated that by decreasing particle size from $15 \mathrm{~mm}$ to $10 \mathrm{~mm}$, biogas production increased by 30.8 , 24.9, 21.86, 23.2, 20.7 and $33.6 \%$ for mixtures A, B, C, D, E and F respectively. While decreasing particle size to $5 \mathrm{~mm}$, biogas production increased by 46.2, 43.9, 42.88, 30.9, 51.7 and $62.9 \%$ comparing with particle size of $15 \mathrm{~mm}$ under the same previous mixtures respectively. The results obtained that the maximum biogas production rate was 8.031 under mixture $\mathrm{D}$ and particle size $5 \mathrm{~mm}$ under retention time of 15 days this is because mixture D contains high fiber content in addition to decreasing in particle size that increase the degree of degradation for mixtures with high fiber content. This is in agreement with Palmowski and Muller (2003).

Cumulative biogas production for all mixtures is shown in Figs. 4 and 5. The results showed that in the beginning, cumulative biogas production was approximated but after the 10 days, cumulative biogas production rate increased for mixture $\mathrm{B}$. cumulative Biogas production yield was 40.32, 38.15, 35.9, 76.4, 36.1, and 41.081 for fermentation mixtures A, B, $\mathrm{C}, \mathrm{D}, \mathrm{E}$ and $\mathrm{F}$ under particle size of $15 \mathrm{~mm}$. 


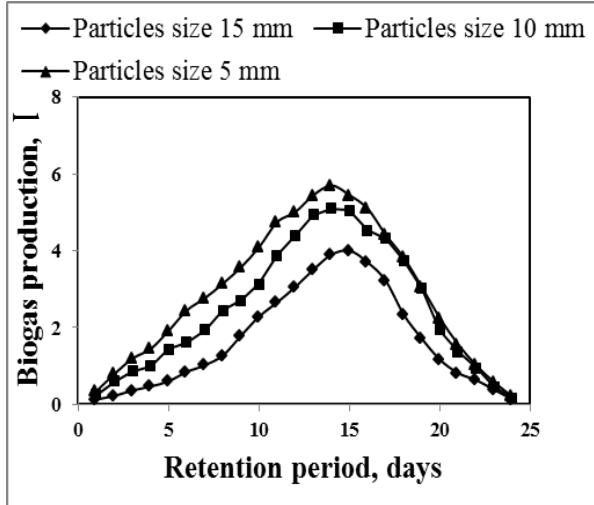

Fermentation mixture (A). [25\% CD+25\% CS+25\% SBW+25\% WH]
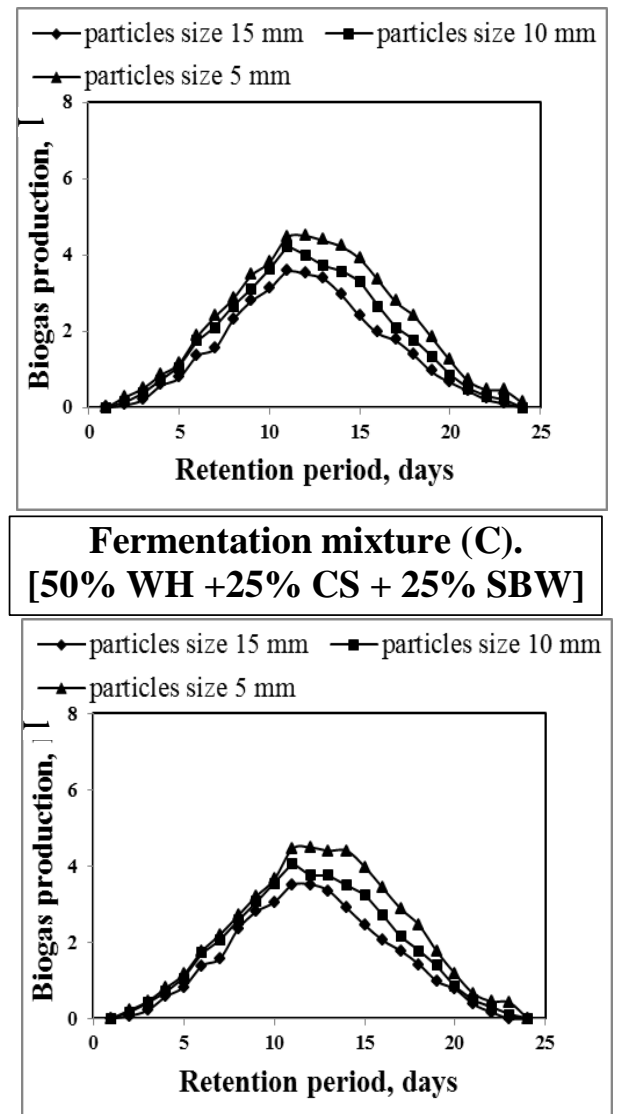

Fermentation mixture (E). [50\% SBW+ 25\% CS + 25\% WH]
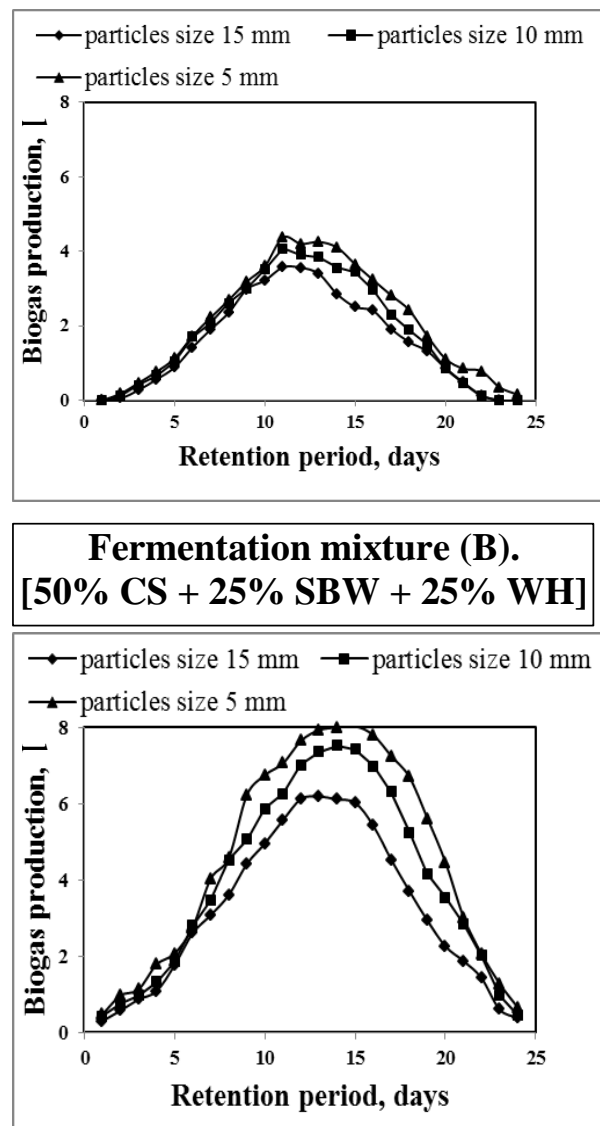

Fermentation mixture (D). [50\% CD +25\% CS + 25\% WH]

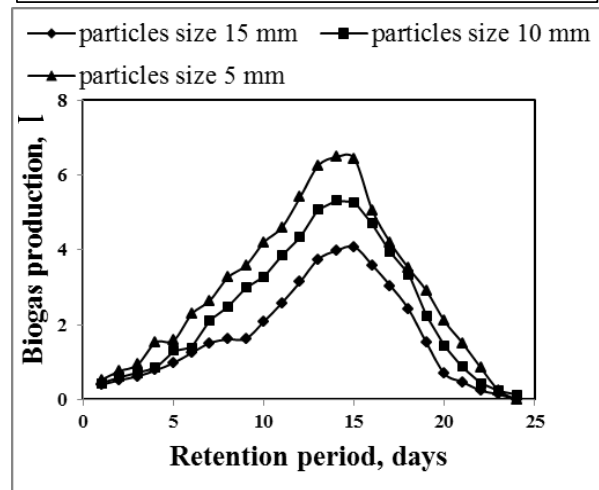

Fermentation mixture (F). [50\% CD +25\% SBW + 25\% WH]

Fig.(3). Biogas production of different fermentation mixtures under different particles sizes. 

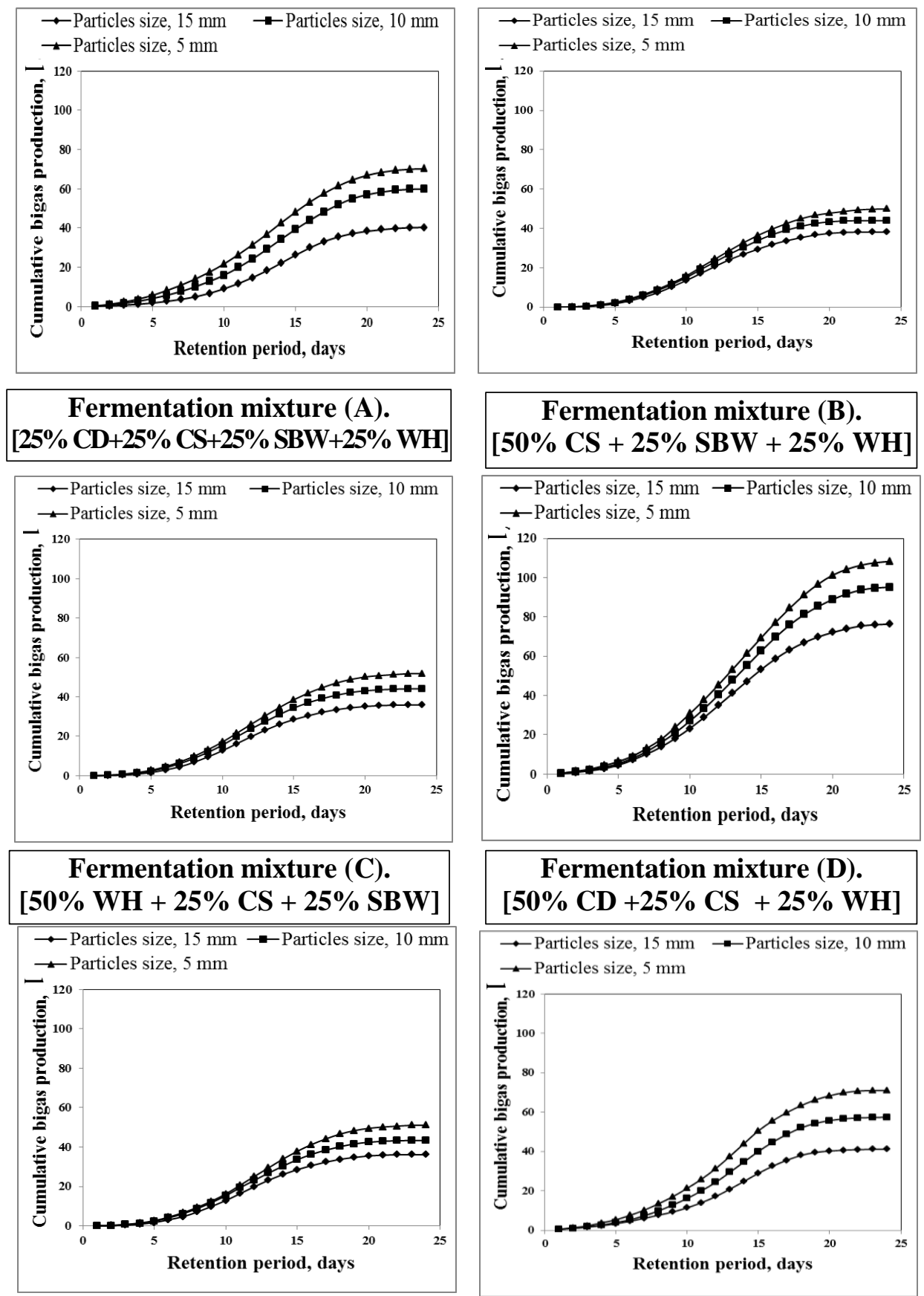

Fermentation mixture (E).

$[50 \% \mathrm{SBW}+25 \% \mathrm{CS}+25 \% \mathrm{WH}]$
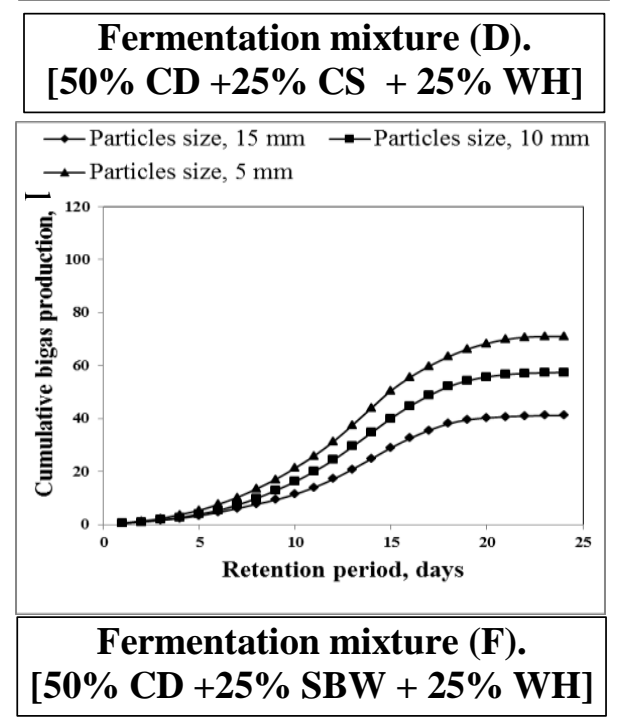

Fig.(4). Cumulative biogas production of different fermentation mixtures under different particles sizes. 


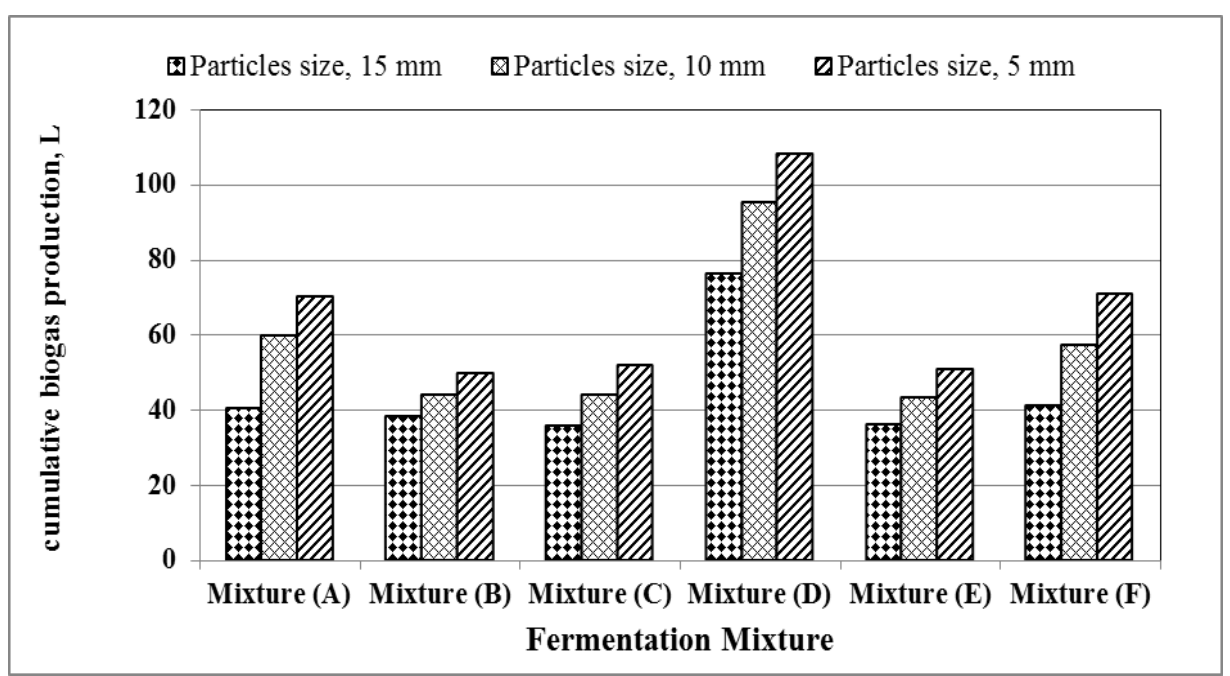

Fig.(5). Cumulative biogas production of different fermentation mixtures under different particles sizes.

These values increased to 59.9, 43.9, 44.1, 95.2, 43.3 and 57.391 for particle size of $10 \mathrm{~mm}$ under the same mentioned fermentation mixtures respectively. While these values reached to the maximum under $5 \mathrm{~mm}$ of particle size and recorded 70.18, 49.94, 51.9, 108.3, 51.06 and 70.941 for mixtures A, B, C, D, E and F respectively.

\section{Effect of fermentation mixtures and particles sizes on methane and methane cumulative production:}

Methane production at different particle sizes for all fermentation mixtures is shown in Fig. 6. The results showed that the maximum methane production was 6.161 for mixture $\mathrm{D}$ and particle size of $5 \mathrm{~mm}$ under retention time 14 days this is due to the composition of mixture $\mathrm{D}$ contains high volatile fatty acid (VFA), so that methane yield increased. While the minimum value was under mixture $D$ this is because of mixture C contains a larger amount of slowly degradable carbohydrates and lignin than other mixtures, so that methane yield decrease. The results obtained that the values of methane production were 4.28, 3.8 and 2.851 for mixture A under particle size of $5 \mathrm{~mm}, 10 \mathrm{~mm}$ and $15 \mathrm{~mm}$ respectively. These values recorded 3.16, 2.74 and 2.141 for mixture B under the same previous particle sizes respectively, and decreased to 3.07, 2.6 and 2.061 
for mixture C. and increased to 6.16, 5.719 and 4.58251 for mixture D. and reached to for 3.26, 2.62 and 2.061 for mixture $E$ and reached to 4.61, 3.79 and 2.72 for mixture $\mathrm{F}$ under the same previous particle sizes respectively. It was noticed that reduction in particle size, increased methane production. The results showed that by decreasing particle size from $15 \mathrm{~mm}$ to $5 \mathrm{~mm}$, methane production yield increased by 50.2, 47.7, 49.03, 34.49, 58.1 and $69.7 \%$ under for mixtures A, B, C D, E and F respectively. This result is similar to (Kouichi et al., 2010 and Mshandete et al. 2006) that said reduction in particle size, increase methane production with about 28, 23, 100 and $60 \%$ for substrates such as food waste, sisal fibre, paper and tomato solids respectively.

Cumulative methane production are shown in Fig. 7 and 8 for different fermentation mixtures. The amount of methane production was 23.4379, 19.79 and13.17 1 for mixtures A under particle size 5, 10 and $15 \mathrm{~mm}$ respectively. They decreased to $17.05,14.84$ and 12.071 for mixture $\mathrm{B}$ under the same mentioned particle sizes. These values reached to 17.23, 14.59 and 11.741 for mixture $C$ under the same previous particle sizes respectively, and increased to $36.9,32.20$ and 25.5 for mixture D. and reached to17.14, 14.5 and 11.86 for mixture $E$ under the same previous particle sizes respectively, and reached to $23.1,18.58$ and 13.031 for mixture $\mathrm{F}$. The results indicated that the maximum methane production value was 36.91 for mixture $\mathrm{D}$ and particle size $5 \mathrm{~mm}$. The results showed that by increasing particle size from $5 \mathrm{~mm}$ to $15 \mathrm{~mm}$, the amount of methane decreased with about, 77.67, 45.8, 46.6, 44.6, 44.5 and 77.2\% for mixtures $\mathrm{B}, \mathrm{C}, \mathrm{D}, \mathrm{E}$ and $\mathrm{F}$ respectively this is due to a larger particle size cause a lower chemical oxygen demand degradation so that lower in methane production this is in agreement with Esposito and et al. (2011).

Effect of fermentation mixtures and particles sizes on total nitrogen percentage in biogas slurry ( $\mathrm{TN}$ ) and $\mathrm{pH}$ value:

Total nitrogen percentages for different fermentation mixtures are shown in Fig. 9. The results showed that total nitrogen percentage for fermentation mixture A was 3.3, 3.4 and $2.2 \%$ under particle sizes of 5, 10 and $15 \mathrm{~mm}$ respectively. These percent reached to 3.8, 3.6 and $2.9 \%$ for mixture B under the same previous particle sizes respectively. These percent reached to the maximum under mixture $\mathrm{C}$ was $4.3,4.1$ and $3.8 \%$ 


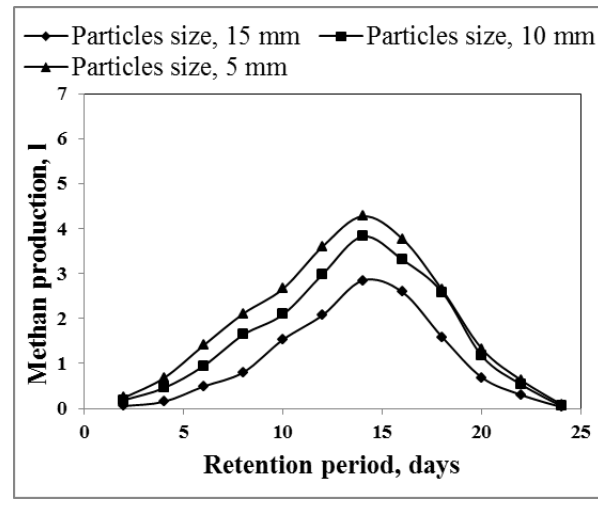

Fermentation mixture (A). $[25 \% \mathrm{CD}+25 \% \mathrm{CS}+25 \% \mathrm{SBW}+25 \% \mathrm{WH}]$

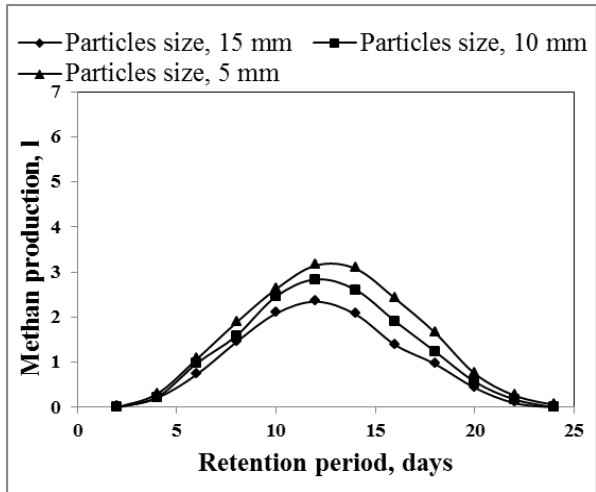

Fermentation mixture (C). $[50 \% \mathrm{WH}+25 \% \mathrm{CS}+\mathbf{2 5} \% \mathrm{SBW}]$

$\longrightarrow$ Particles size, $15 \mathrm{~mm} \rightarrow$ Particles size, $10 \mathrm{~mm}$ $\rightarrow$ Particles size, $5 \mathrm{~mm}$

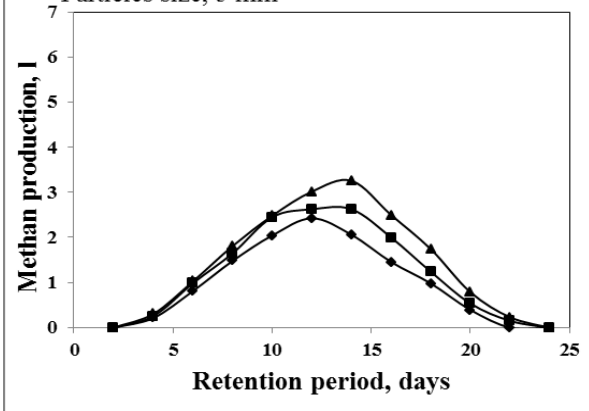

Fermentation mixture (E). $[50 \% \mathrm{SBW}+25 \% \mathrm{CS}+25 \% \mathrm{WH}]$

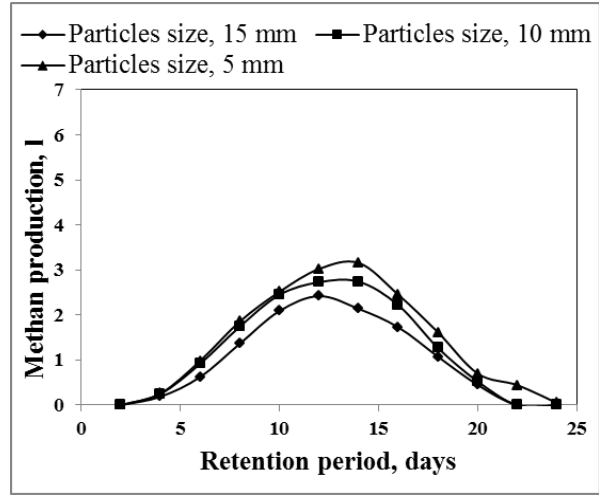

Fermentation mixture (B). $[50 \% \mathrm{CS}+25 \% \mathrm{SBW}+25 \% \mathrm{WH}]$

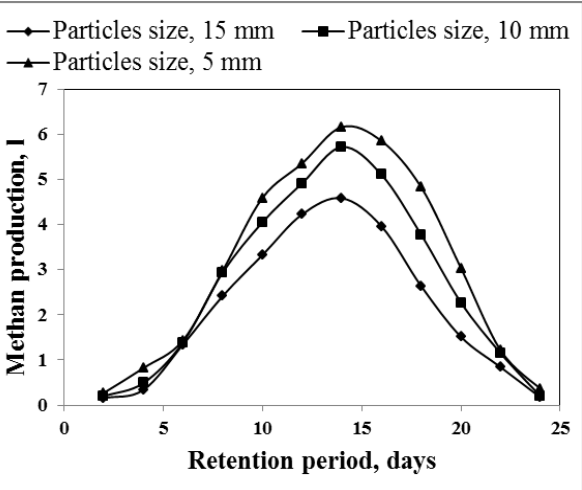

Fermentation mixture (D). $[50 \% \mathrm{CD}+25 \% \mathrm{CS}+25 \% \mathrm{WH}]$

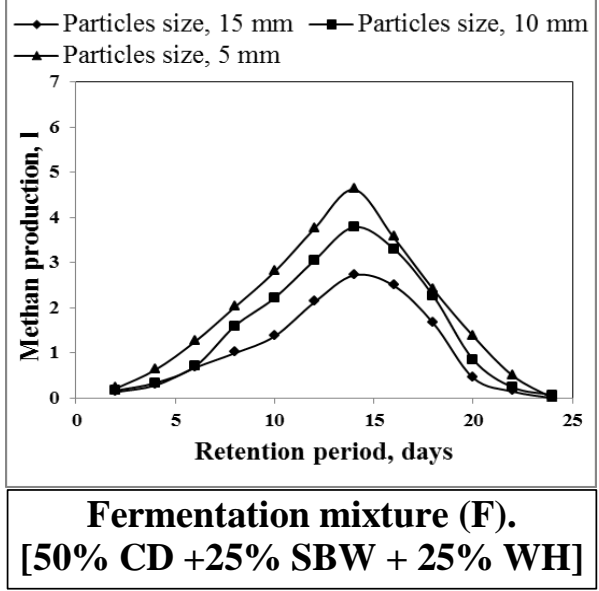

$[50 \% \mathrm{CD}+25 \% \mathrm{SBW}+25 \% \mathrm{WH}]$

Fig.(6). Methane production of different fermentation mixtures under different particles sizes. 


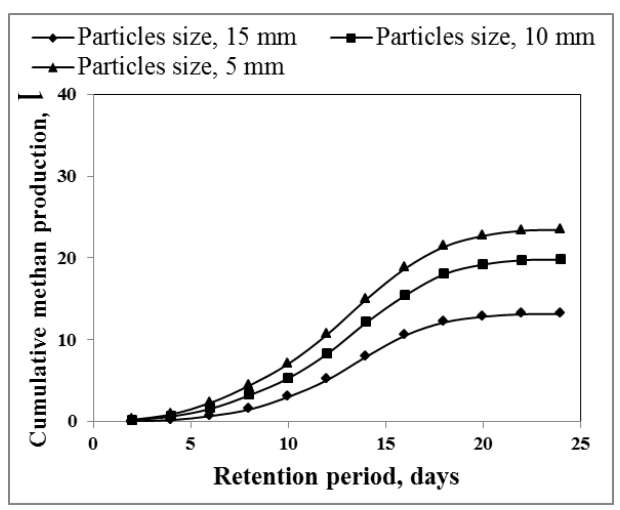

Fermentation mixture (A). $[25 \% \mathrm{CD}+25 \% \mathrm{CS}+25 \% \mathrm{SBW}+25 \% \mathrm{WH}]$

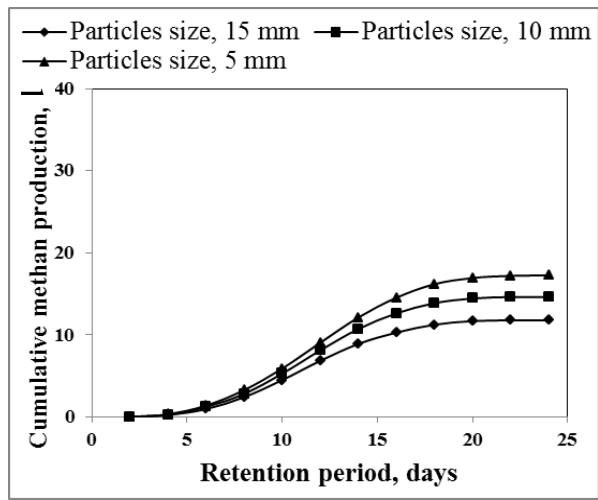

Fermentation mixture $(\mathbf{C})$. $[50 \% \mathrm{WH}+25 \% \mathrm{CS}+25 \% \mathrm{SBW}]$

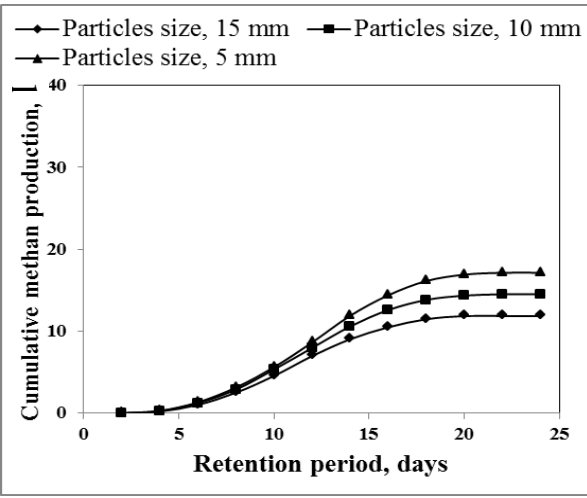

Fermentation mixture (E). $[50 \% \mathrm{SBW}+25 \% \mathrm{CS}+25 \% \mathrm{WH}]$

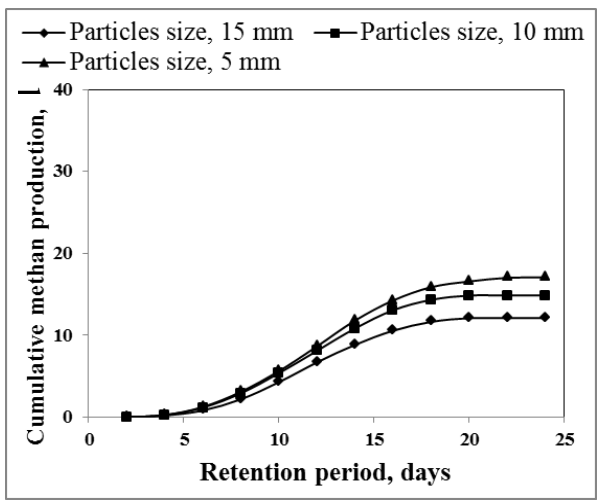

Fermentation mixture (B). $[50 \% \mathrm{CS}+25 \% \mathrm{SBW}+25 \% \mathrm{WH}]$

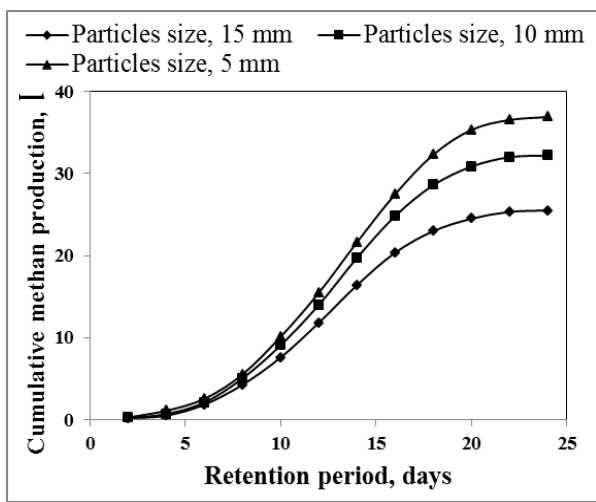

Fermentation mixture (D). $[50 \% \mathrm{CD}+25 \% \mathrm{CS}+\mathbf{2 5} \% \mathrm{WH}]$

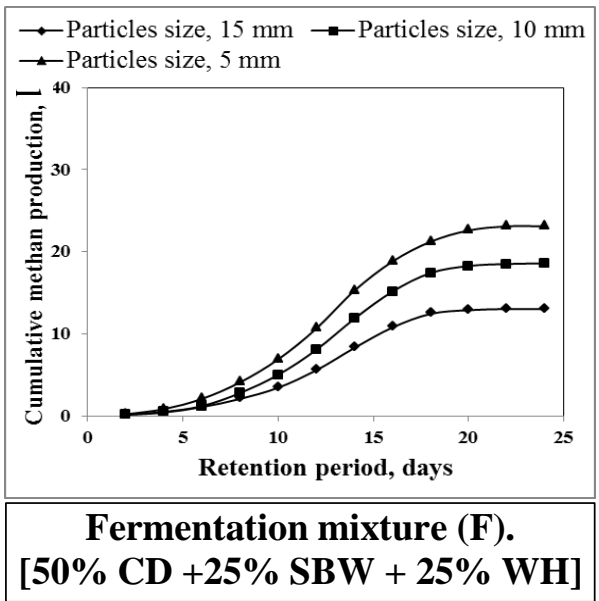

Fig. (7).Cumulative methane production of different fermentation mixtures under different particles sizes. 


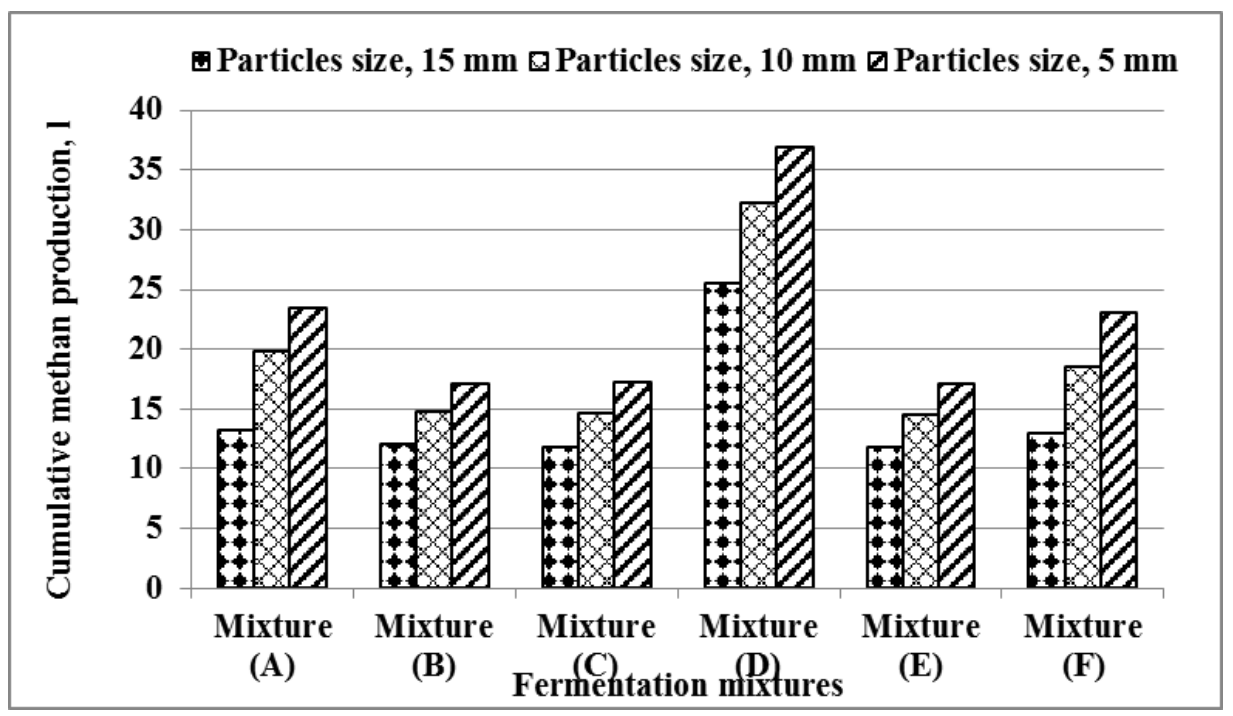

Fig. (8). Cumulative methane production of different fermentation mixtures under different particles sizes.

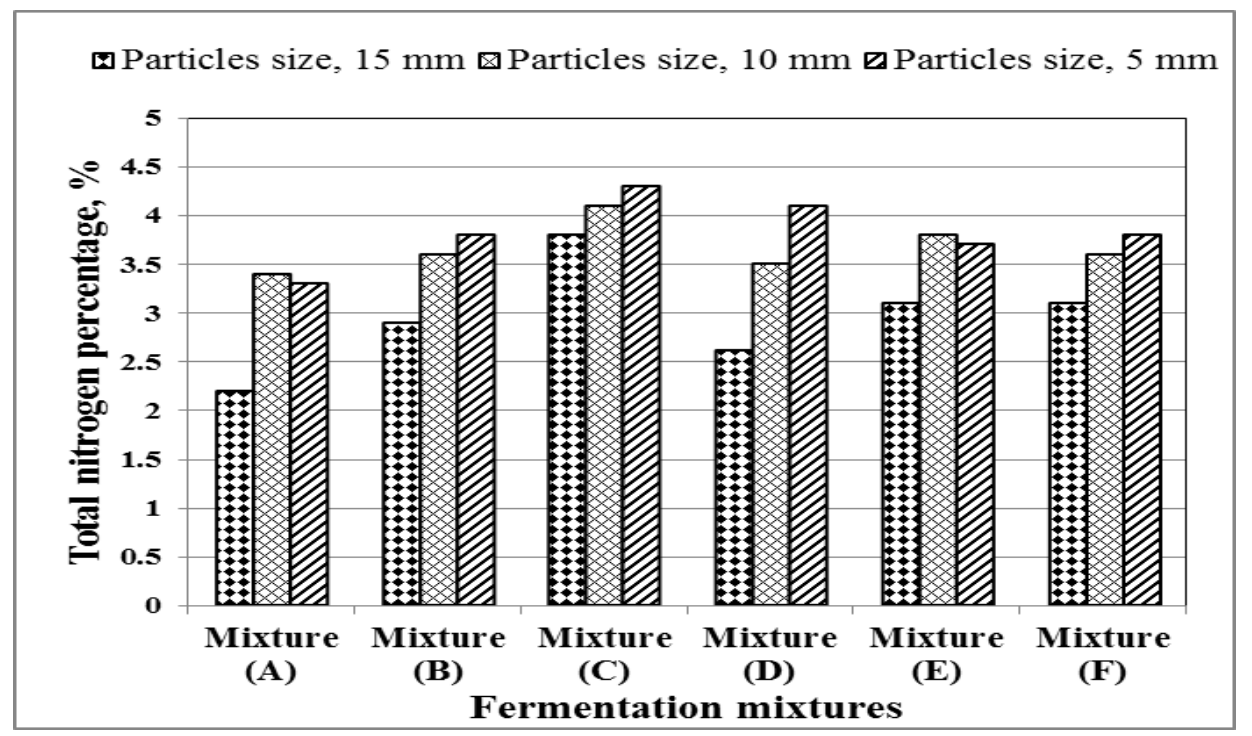

Fig.(9).Total nitrogen percentage of different fermentation mixtures under different particles sizes.

for 5,10 and $15 \mathrm{~mm}$ respectively this is because of the reverse relationship between methane production and nitrogen percentage. But these value reached to $4.1,3.5$ and 2.62 for mixture $D$ under the same previous thickness respectively. These values decreased to 3.7, 3.8 and 
$3.1 \%$ for mixture $\mathrm{E}$ under the same mentioned particle sizes and reached to 3.8, 3.6 and 3.1 for mixture $\mathrm{F}$. The results indicated that the highest nitrogen percentage was $4.3 \%$ under mixture $\mathrm{C}$ and particle size $5 \mathrm{~mm}$ but the minimum was $2.2 \%$ under these properties mixture A and particle size $15 \mathrm{~mm}$.

$\mathrm{pH}$ values for different fermentation mixtures and particle sizes are shown in Fig. 10. It was noticed that the maximum $\mathrm{pH}$ values were 6.77, 6.74 and 6.83 for particle sizes of 5,10 and $15 \mathrm{~mm}$ under fermentation mixture B. This is because of an increase in $\mathrm{C} / \mathrm{N}$ ratio of mixture resulted to better $\mathrm{pH}$ stability and enhanced methanogenic activities. While the minimum values were 6.7, 6.65 and 6.6 for mixture A under the same previous particle sizes respectively.

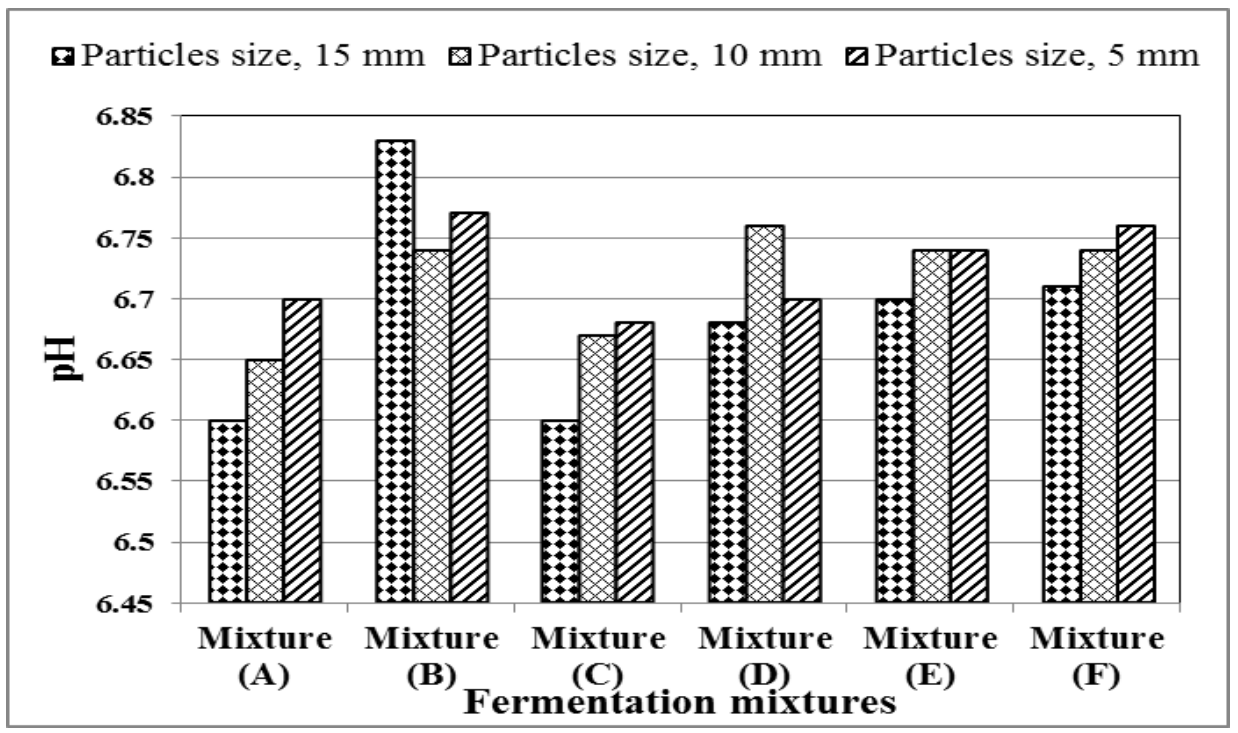

Fig.(10).pH of different fermentation mixtures under different particles sizes.

\section{CONCLUSION}

\section{The present study recommended the following:}

1-The suitable particle size was $5 \mathrm{~mm}$ for producing the maximum biogas and methane percentage

2- Methane production was in the optimum region under the use of mixture D

3- The maximum percentage of nitrogen and $\mathrm{pH}$ were found for mixtures $\mathrm{C}$ and $\mathrm{B}$ respectively. 


\section{REFERENCES}

Abdel-Hadi, M. A. and S. A. M. Abd El-Azeem (2008).Effect of heating, mixing and digester Type on biogas Production from buffalo dung.Misr J. Ag. Eng., 25(4): 1454-1477

Agricultural Economics Bulletin (2016). Ministry of Agriculture, Cairo, Egypt

Angelidaki, I. and B.K. Ahring (2000).Methods for increasing the biogas potential from the recalcitrant organic matter contained in manure. Water Sci Technol, 41(3):189-94.

Eltawil M. A. And E. B. A. Belal. (2009) evaluation and scrubbing of biogas generation from agricultural wastes and water hyacinth.Misr J. Ag. Eng., 26(1): 534- 560.

Esposito, G., L. Frunzo, A. Panico and F. Pirozzi (2011). Modeling the effect of the OLR and of MSW particle size on the performance of an anaerobic co-digestion reactor. Brocess Biochem 4(6):557-560

Ezekoye, V. A. and C. E. Okeke (2006). Design, construction, and performance evaluation of plastic biodigester and the storage of biogas. The Pacific Journal of Science and Technology, 7(2), 176-184.

Faure, D. and A. M. Deschamps (1990). Physico-chemical and microbiological aspects in composting of grape pulps. Biological wastes, 34(3), 251-258.

Gosch A., M. Hildegart, W. Ursula and J. Walter. (1983). The anaerobic treatment of poultry manure, Animal Res. and Dev., 17: 62-73.

GTZ-GATE (1999). Biogas Digest (Volume I. Biogas Basics) GTZGATE.Eschborn, Germany. http://www2.gtz.de/dokumente/bib/045364.pdf

Hartmann, H.; I. Angelidaki And B.K. Ahring (2000). Increase of anaerobic degradation of particulate organic matter in full-scale biogas plants by mechanical maceration. Water Sci Technol ;41(3):145-53.

Kivaisi, A.K. and S. Eliapenda (1994). Pre-treatment of bagasse and coconut fibres for enhanced anaerobic degradation by rumen microorganisms. Renew Energy ;5(2):791-5.

Kouichi, I, Y. K. Okishio, N. Nagao, C. Niwa, S. Yamamoto and T. Toda (2010). Effects of particle size on anaerobic digestion of food waste. International Biodeterioration \& Biodegradation 64: 601-608 
Mshandete, A.; L.Björnsson; A. K. Kivaisi; M. S. Rubindamayugi and B. Mattiasson (2006). Effect of particle size on biogas yield from sisal fibre waste. Renewable energy, 31(14), 2385-2392.

Palmowski, L. M., and J. A. Müller (2000). Influence of the size reduction of organic waste on their anaerobic digestion. Water science and technology, 41(3), 155-162.

Raheman, H. And S. Mondal (2012). Biogas production potential of jatropha seed cake. Biomass and Bioenergy.Volume 37, 25-30

Ukpai, P. A. and M. N. Nnabuchi (2012) Comparative study of biogas production from cow dung, cowpea and cassava peeling using 45 litres biogas digester. Advances in Applied Science Research. 3 (3): 1864-1869.

الملخص العزبي

\section{تأثير نوع مخلوط التخمر وحجم الحبيبات على ناتج الغاز الحيوي من المخلفات العضوية و الزراعية}

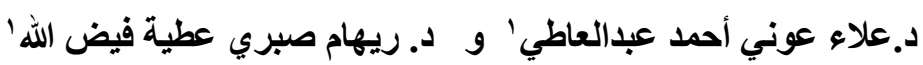

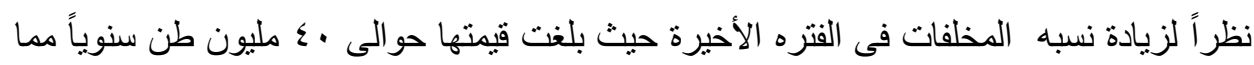

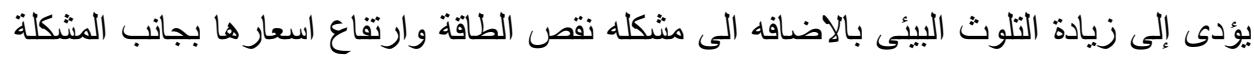

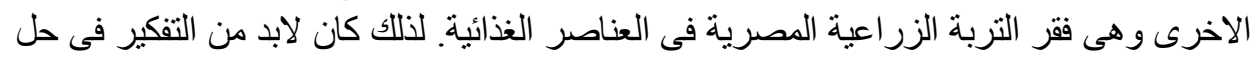

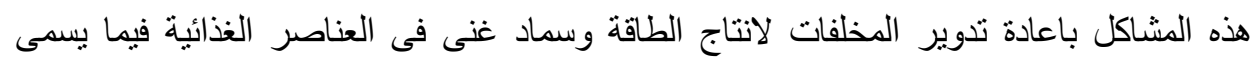

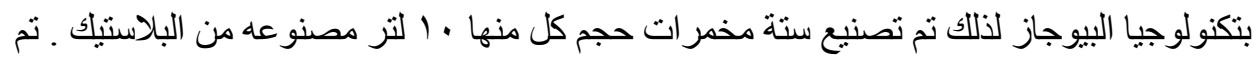

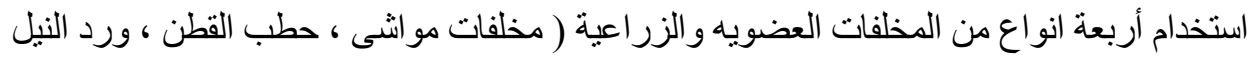

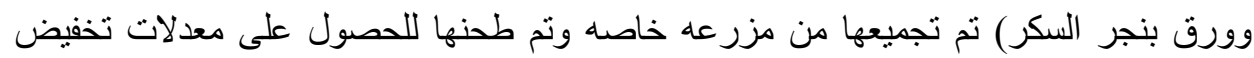

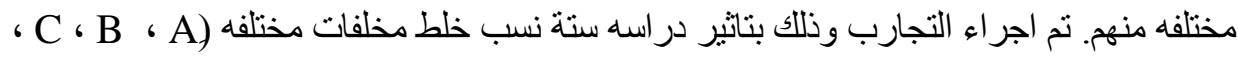

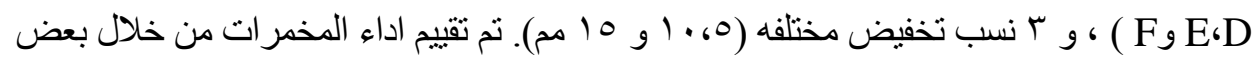

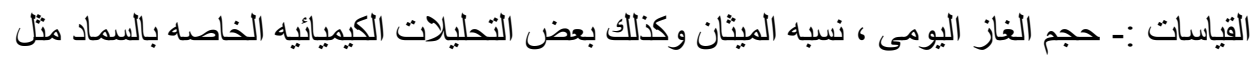

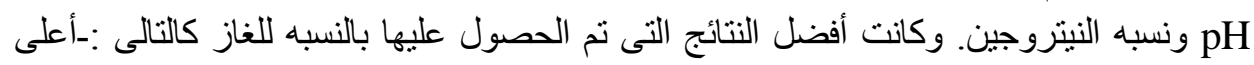

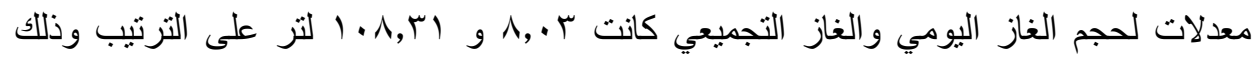

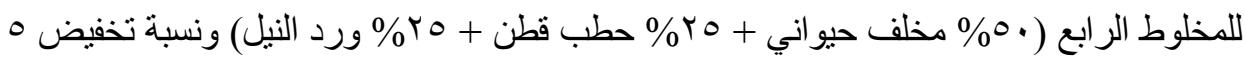

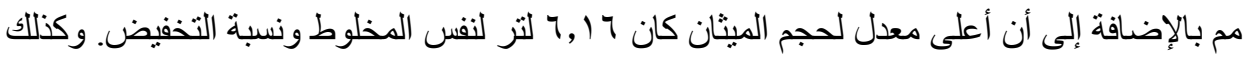

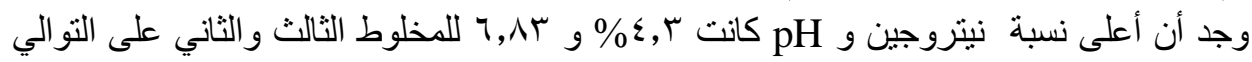

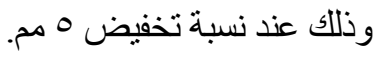

' مدرس بقسم الهندسة الزراعية - كلية الزراعة - جامعة الزقازيق 